\title{
ESPAÇO E COMUNIDADE EM FACE DE GRANDES PROJETOS PÚBLICOS: CONFLITOS E RESISTÊNCIA EM FACE DA AÇÃO GOVERNAMENTAL
}

\section{SPACE AND COMMUNITY IN THE FACE OF LARGE PUBLIC PROJECTS: CONFLICT AND RESISTANCE IN THE FACE OF GOVERNMENT ACTION}

\author{
Juliana Arruda ${ }^{1}$ \\ Raphaella Santos de Souza² \\ Wellington Mary ${ }^{3}$
}

\section{Resumo}

É sabido que as reformas urbanas devem ocorrer para abranger toda a população que cresce espontaneamente nas cidades. Entretanto, a forma com que estão ocorrendo as intervenções, com remoções sem respeito à legislação, precisa ser investigada e divulgada. O presente artigo, oriundo de uma pesquisa de dissertação, tem a pretensão de apontar as legislações que não foram respeitadas, em função de metas econômicas e de "desenvolvimento", além disso, descrever as relações sociais que eram estabelecidas pelo grupo de moradores da comunidade de Vila das Torres-Madureira, cuja dissolução ocorre em função do deslocamento dos mesmos para a implantação de uma área de lazer intitulada, Parque Madureira, realizada pela Prefeitura Municipal do Rio de Janeiro. Junto a essa ação governamental ocorreu também à descontinuidade dos contratos de comodato da Light com os moradores daquela comunidade que desenvolviam atividades agrícolas sob as linhas de transmissão dessa companhia. Por isso, é conclusivo que o empreendimento, objeto da pesquisa, se coaduna com a gestão da cidade baseada em reformas e renovações urbanas, já que, permanência de moradores irregulares em determinado local da cidade tem o a propósito de realizar um estoque de terras, a qual será usada no momento em que o Governo achar conveniente.

Palavras-chaves: Agricultura Urbana, Parque Madureira, Direito à cidade.

\begin{abstract}
It is known that urban reforms must take place to cover the entire population that grows spontaneously in cities. However, the way interventions are being made, with withdrawal without regard to legislation, must be investigated and disclosed. This article, originated from a research dissertation, aims to point the laws that are not fulfilled due to economic goals and "development", in addition, aims to describe the social relations that were established by community residents group Vila das Torres-Madureira, whose dissolution is a function of displacement of the same for the implementation of a recreation area titled, Madureira Park, held by the Municipality of Rio de Janeiro. Along with this government action was also the discontinuity of the lease agreements of Light with the residents of that community that developed agricultural activities under the transmission lines of that company. Therefore, it is conclusive that the project, object of the research is consistent with the city management based on urban reforms and renovations, since

\footnotetext{
${ }^{1}$ Doutora pelo CPDA/UFRRJ. Pró-reitora adjunta de assuntos estudantis na UFRRJ e professora do Colégio Técnico da UFRRJ. E-mail: japarana@hotmail.com

2 Mestre pelo CPDA/UFRRJ 2015. Atualmente estudante como aluna especial da UENF-RJ. E-mail: santos.raphaella@bol.com.br

3 Doutor em Engenharia Agrícola pela Universidade Estadual de Campinas em Construções Rurais e Ambiência. Professor adjunto da UFRRJ.E-mail: wmary2@hotmail.com.br
} 
permanence of irregular residents in a certain place of the city is the the purpose of making an inventory of land, which will be used at the time that the Government sees fit.

Keywords: Urban Agriculture, Madureira Park, right to the city. 
O presente artigo traz algumas discussões da Dissertação intitulada "Espaço e comunidade em face de grandes projetos públicos: o deslocamento involuntário de moradores/agricultores de Vila das Torres, Madureira (Rio de Janeiro) ", publicada em 2015, que versou sobre a remoção de moradores/agricultores de uma comunidade vulnerável socioeconomicamente, chamada Vila das Torres, localizada no bairro de Madureira, realizada pela Prefeitura Municipal do Rio de Janeiro. Junto a essa ação governamental ocorreu também a descontinuidade dos contratos de comodato ${ }^{4}$ da Light com os moradores daquela comunidade que desenvolviam atividades agrícolas sob as linhas de transmissão dessa companhia. Ambas as ações ocorreram para a implantação de um parque público, chamado Parque Madureira, no espaço que antes era ocupado pelas hortas e atores citados.

O trabalho em questão envolve dois processos em curso diretamente relacionados. O reassentamento/remoção dos moradores e a realocação da Agricultura Urbana, trazendo danos financeiros e pessoais à população residente, tendo como agentes envolvidos a Light, a Prefeitura, os moradores e os agricultores de Vila das Torres.

É sabido que as reformas urbanas devem ocorrer para abranger toda a população que cresce espontaneamente nas cidades. Entretanto, a forma com que estão ocorrendo às intervenções urbanas, com remoções sem respeito à legislação, ignorando completamente o princípio da não remoção instituído no Plano Diretor $^{5}$ e Lei Orgânica do Município do Rio de Janeiro $^{6}$, além da não consideração do histórico cultural, social, econômico e agrícola (nesse caso específico) que os moradores de Vila das Torres possuíam no local de origem, foram investigados nesse trabalho.

Por conta do exposto o objetivo do trabalho é sinalizar as legislações que não foram respeitadas em função de metas econômicas e "desenvolvimento", além de apontar as relações sociais que eram estabelecidas pelo grupo de moradores vulneráveis, cuja dissolução ocorre em função do deslocamento dos mesmos para a implantação da área de lazer, além de apontar as

\footnotetext{
${ }^{4}$ No art. 579 do Código Civil de 2002 "Comodato é o empréstimo gratuito de coisas não fungíveis (que não podem ser substituídas por outras de mesmo gênero, qualidade e quantidade, independentemente do valor). Perfaz-se com a tradição do objeto". Ou seja, comodato é um negócio jurídico unilateral gratuito, pelo qual uma das partes (comodante) entrega à outra (comodatário) a posse de um determinado bem, móvel ou imóvel, para que se sirva dela, com obrigação de o restituí-las no mesmo estado em que as recebeu (GAGLIANO, 2014).

5 Disponível em: < http://mail.camara.rj.gov.br/APL/Legislativos/contlei.nsf/573ad0b372ea8c96032564ff00629eae/758414dfee 085d47032577220075c7e4?OpenDocument > Acesso em: nov. 2015

${ }^{6}$ Disponível em: < http://www2.rio.rj.gov.br/pgm/leiorganica/leiorganica.html > Acesso em: nov. 2015.
} 
repercussões e violações ocorridas durante a desapropriação que resultou na exclusão dos indivíduos e de suas famílias.

O empreendimento (Parque Madureira) que substituiu a produção agrícola na região teve sua obra iniciada em 2011, e a comunidade, como um todo, já tinha sido removida e os contratos de comodatos estabelecidos com a empresa Light encerrados.

Em 2012 (ano de eleição municipal) o local foi aberto ao público, ainda em fase de acabamento. O projeto de implementação foi realizado pela Prefeitura Municipal do Rio de Janeiro em parceria com o Grupo Light e a empresa Delta. Uma parceria público-privada ${ }^{7}$ que é considerada um meio eficaz, quando firmada de acordo e respeitando a legislação vigente sobre o assunto, para obtenção de recursos da iniciativa privada destinados a serviços públicos e setores de pouca viabilidade econômica quando prestados exclusivamente pelo Poder Público.

Tal parceria foi utilizada como estratégia de recuperação financeira, para o enfrentamento da crise econômica internacional de 2008 que estava em curso, do Programa de Aceleração do Crescimento $^{8}$, com o Programa Minha Casa Minha Vida (PMCMV) ${ }^{9}$. Segundo a Assitente Social da Secretaria Municipal de Habitação em 2010 foram cadastrados, 843 domicílios, dos quais 57 eram comércio, destes 326 famílias foram reassentadas ${ }^{10}$ no PMCMV, as demais 460 optaram por

\footnotetext{
7 A definição legal do instituto da Parceria Público-Privada que consta no art. 2o da Lei Federal no. 11.079/2004 é: "o contrato administrativo de concessão na modalidade patrocinada ou administrativa". Ou seja, as parcerias público-privadas são contratos que estabelecem vínculo obrigacional entre a Administração Pública e a iniciativa privada visando à implementação ou gestão, total ou parcial, de obras, serviços ou atividades de interesse público, em que o parceiro privado assume a responsabilidade pelo financiamento, investimento e exploração do serviço, observando, além dos princípios administrativos gerais, os princípios específicos desse tipo de parceria. Entretanto, existem diversas modalidades para tal contrato. E a que se encaixa no caso estudado na presente pesquisa é a Concessão Administrativa, pois segundo a mesma Lei "Concessão administrativa é o contrato de prestação de serviços de que a Administração Pública seja a usuária direta ou indireta, ainda que envolva execução de obra ou fornecimento e instalação de bens." Ou seja, quando não é possível ou conveniente cobrar do usuário pelo serviço de interesse público prestado pelo parceiro privado, sendo a remuneração da empresa integralmente feita por pelo poder público.

8 Programa de Aceleração do Crescimento - PAC - é um programa que tem como propósito o crescimento econômico, o aumento dos postos de emprego e a melhoria das condições de vida da população brasileira, alcançados por meio de um conjunto de medidas destinadas a incentivar o investimento privado, aumentar o investimento público em infraestrutura e remover obstáculos burocráticos, administrativos, normativos, jurídicos e legislativos ao crescimento.

9 O Programa Minha Casa Minha Vida (PMCMV), lançado no ano de 2009, na gestão de 2006-2010 do então Presidente da República, é um programa do Governo Federal, gerido pelo Ministério das Cidades e operacionalizado pela Caixa Econômica Federal (CEF) com o objetivo de implantar o Plano Nacional de Habitação.

10 Reassentamento é definido como a remoção definitiva de famílias para outras áreas, preferencialmente próximas às áreas de intervenção, por ocuparem áreas de risco, de preservação permanente ou por necessidade de desadensamento (VIEIRA e BAGNATORI, 2013). Entretanto, os atores estudados não foram
} 
receber indenização. Em 2011 a Secretaria de Habitação retornou para cadastrar os moradores da chácara, 72 famílias $^{11}$, e todos foram indenizados, pois não tinha mais apartamento do PMCMV para oferecer. Ou seja, foram realizados 915 cadastramentos, desses 57 eram comércio e 858 residências familiares. Desse último 326 famílias foram para o PMCMV, parte em Realengo e outras no bairro de Campo Grande e 532 foram indenizadas. Não foram disponibilizadas informações quanto às negociações em relação às pessoas que possuíam comércio na comunidade. Nenhum gestor conseguiu responder qual era o número exato de pessoas das comunidades, entretanto todos de uma forma unânime estimaram mais de 4 mil pessoas realocadas.

A realocação da comunidade por parte da Prefeitura não considerou as áreas que os indivíduos mantinham com produção de gêneros agrícolas, ficando responsável a empresa Light pelas indenizações referentes à horta. Entretanto, é importante deixar claro que em momento algum a empresa informou que estava pagando indenizações, a mesma afirmou que estava oferecendo uma ajuda de custo por levarem em consideração o tempo que os comodatários se encontravam no terreno, alegaram também que segundo o contrato, estabelecido pelas partes, não seria necessário nenhum tipo de pagamento ao requerer o terreno.

Após a definição do objeto de estudo e do estabelecimento dos objetivos que se desejou alcançar com a pesquisa, optou-se pela utilização da pesquisa científica qualitativa, pois a partir desta, seria possível entender e analisar os fenômenos que envolvem os seres humanos e suas intrínsecas relações sociais, estabelecidas em diversos ambientes (GODOY, 1995a). Os estudos denominados qualitativos têm como preocupação fundamental o estudo e a análise do mundo empírico em seu ambiente natural (GODOY, 1995b). No entanto, o tipo de pesquisa qualitativa a ser usada será o estudo de caso, pois segundo Oliveira (2014) o mesmo deve ser aplicado quando o pesquisador tem o interesse em pesquisar uma situação singular, particular.

Tal tipo de pesquisa consiste em interpretar um contexto particular e relatar a complexidade da situação a ser estudada de forma completa e profunda, transformando o empírico em algo documentável, além de representar os diferentes e às vezes conflitantes pontos de vista presentes na tal situação social. No caso em questão, a remoção dos

reassentados em regiões próximas e não apresentaram tais necessidades de intervenção, apesar do governo citar a proximidade com a linha férrea como um fator de risco.

${ }^{11}$ No cadastramento da Prefeitura foram constatadas 72 famílias morando no espaço da horta, entretanto como dito anteriormente, apenas 47 agricultores exerciam a função agrícola na área. 
moradores/agricultores da comunidade de Vila das Torres para a implantação do Parque Madureira.

As entrevistas foram realizadas em diferentes locais (a maioria na nova casa dos moradores, nas barracas dos agricultores, nos escritórios dos gestores), umas marcadas previamente, outras ocorreram na primeira abordagem do ator. A autora também procurou fazer com que todas as entrevistas fluíssem como uma conversa informal, ou seja, não houve interrupções/pausas entre perguntas e respostas, umas únicas perguntas, na maioria das vezes, desencadeavam diversas respostas relacionadas ao questionário aplicado, assuntos paralelos eram comentados como forma de desabafo, uns falavam livre e abertamente sobre o assunto outros nem tanto.

Por isso os nomes dos informantes são fictícios, criados para dar mais proximidade ao contexto estudado. Notar-se-á que as iniciais dos nomes criados acompanham as iniciais dos grupos aos quais os agentes estudados pertencem. Exemplo: morador, Moacir; agricultor, Agripino entre outros. E as falas obtidas durante as conversas que serão apresentadas ao longo do texto, serão possíveis perceber que estarão acompanhadas de notas de rodapé, recurso utilizado para que se identifique o ator entrevistado.

Tal trabalho fará um relato, uma demonstração de como ocorreu o deslocamento, não só dos moradores, mas também da única fonte de renda de alguns, e isso a partir da percepção dos próprios moradores/agricultores. Para fins de contextualização do espaço em que ocorreu o estudo será caracterizado o bairro de Madureira para revelar o porquê do interesse dos gestores públicos e privados pelo mesmo e posteriormente a comunidade de Vila das Torres.

\section{AS TRANSFORMAÇÕES SOCIOESPACIAIS DO BAIRRO MADUREIRA NA PRIMEIRA DÉCADA DO SÉCULO XXI}

Madureira é um bairro da Zona Norte da cidade do Rio de Janeiro, como mostra a figura 1. Sua população é basicamente de Média classe média (renda per capita: até 641,0012) e Baixa classe média (renda per capita: até 441,00), incluindo algumas comunidades carentes, como a antiga comunidade de Vilas das Torres, entretanto apesar de ter sido retirada a grande parte da comunidade, ainda é possível encontrar 370 familias remanescentes. O bairro pertence a XV Região Administrativa que compreende, além do bairro estudado, os bairros de Campinho,

12 Fonte: http://www.sae.gov.br/site/?p=17821\#ixzz2zd02B9s1 
Quintino Bocayúva, Cavalcanti, Engenheiro Leal, Cascadura, Vaz Lobo, Turiaçú, Rocha Miranda, Honório Gurgel, Oswaldo Cruz, Bento Ribeiro e Marechal Hermes.

Madureira em 2010 possuía, segundo os dados registrados no sitio virtual da Prefeitura, Armazém de Dados, uma população de 50.106 habitantes - apesar de sua população flutuante ser muito maior que isso - destes 22.944 são homens e 27.162 são mulheres, com 18.937 domicílios. Ocupa uma extensão de 378,76ha, desses 0,03\% (0,12ha) é vegetação secundaria; 88,91\% (336,75ha) é área urbana; 1,43\% (5,43ha) é agricultura; 3,46\% (13,12ha) é vegetação arbórea arbustiva e, 5,21\% (19,72ha) é reflorestamento. Apresenta também 2.035.056,2m², no ano de 2005, de área de conservação ambiental, APARU da Serra da Misericórdia ${ }^{13}$ (ARMAZEM, 2013).

Na educação apresenta na rede pública municipal 6 escolas e 5 creches, totalizando 3.589 matrículas. Quanto ao uso territorial o bairro apresenta um total de área construída de $906.397 \mathrm{~m}^{2}$, sendo desses $452.037 \mathrm{~m}^{2}$ são de casa-sobrado e isso corresponde a 6.514 unidades; 13.733 imóveis; 7.020 apartamentos; 182 casas-apartamento e, 17 outras tipologias (ARMAZEM, 2013).

É importante deixar claro que tais dados, apesar de terem sido os mais recentes encontrados (anos 2010/2011), foram totalizados antes do processo de remoção da comunidade e construção do Parque. Logo pode ser que esteja em desacordo com o período atual (ano 2014).

\footnotetext{
${ }^{13}$ APARU - Área de Proteção Ambiental e Recuperação Urbana - de domínio público ou privado, que depende de ações do Poder Público para a regulação do uso e ocupação do solo e restauração de suas condições ecológicas e urbanas (ARMAZEM, 2013). A Serra da Misericórdia abrange cerca de $43,9 \mathrm{~km}^{2}$ no município do Rio de Janeiro, e estende-se por 27 bairros do subúrbio carioca: Abolição, Bonsucesso, Brás de Pina, Cavalcante, Cascadura, Complexo do Alemão, Del Castilho, Engenho da Rainha, Higienópolis, Honório Gurgel, Inhaúma, Irajá, Madureira, Olaria, Penha, Penha Circular, Piedade, Pilares, Ramos, Rocha Miranda, Tomas Coelho, Turiaçu, Vaz Lobo, Vicente de Carvalho, Vila Kosmos e Vista Alegre.
} 
Figura 1. Localização espacial do bairro de Madureira no Município do Rio de Janeiro.

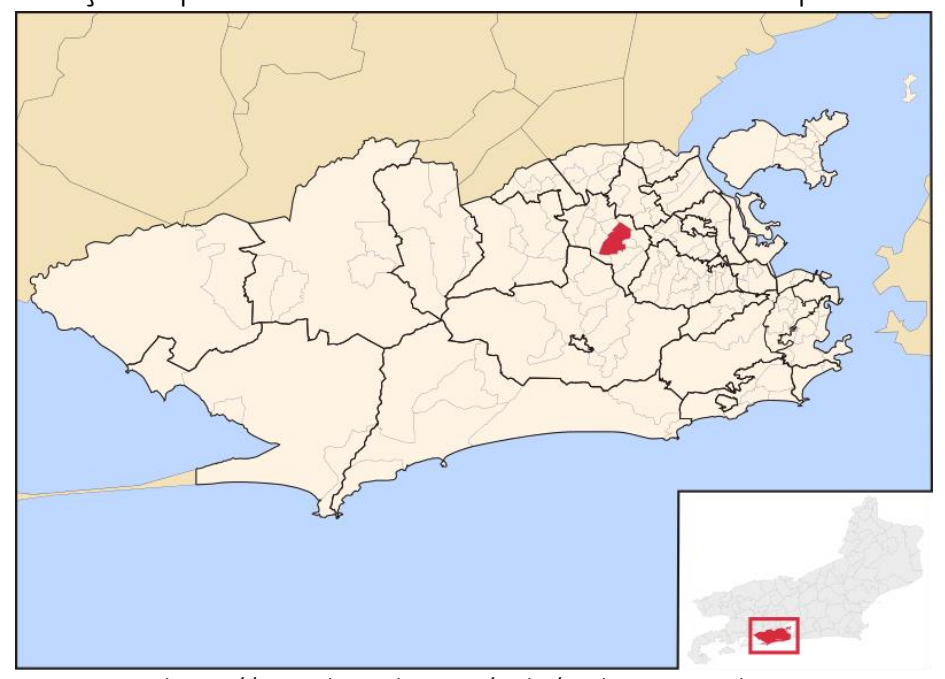

Fonte: http://pt.wikipedia.org/wiki/Ficheiro:Madureira.svg

Seus destaques ficam por conta de uma imensa amplitude de linhas de ônibus e sua variedade de estabelecimentos comerciais, sendo o segundo pólo comercial e econômico da cidade e o maior do subúrbio do Rio de Janeiro. E atualmente a imensa área de lazer intitulada, Parque Madureira, figura 2, que será brevemente caracterizado a seguir, tendo como base para tal, os dados divulgados pelos órgãos oficiais. É importante esclarecer que este projeto final não foi o apresentado à comunidade pela Prefeitura no início do processo de remoção.

Figura 2. Visão panorâmica do Parque Madureira.

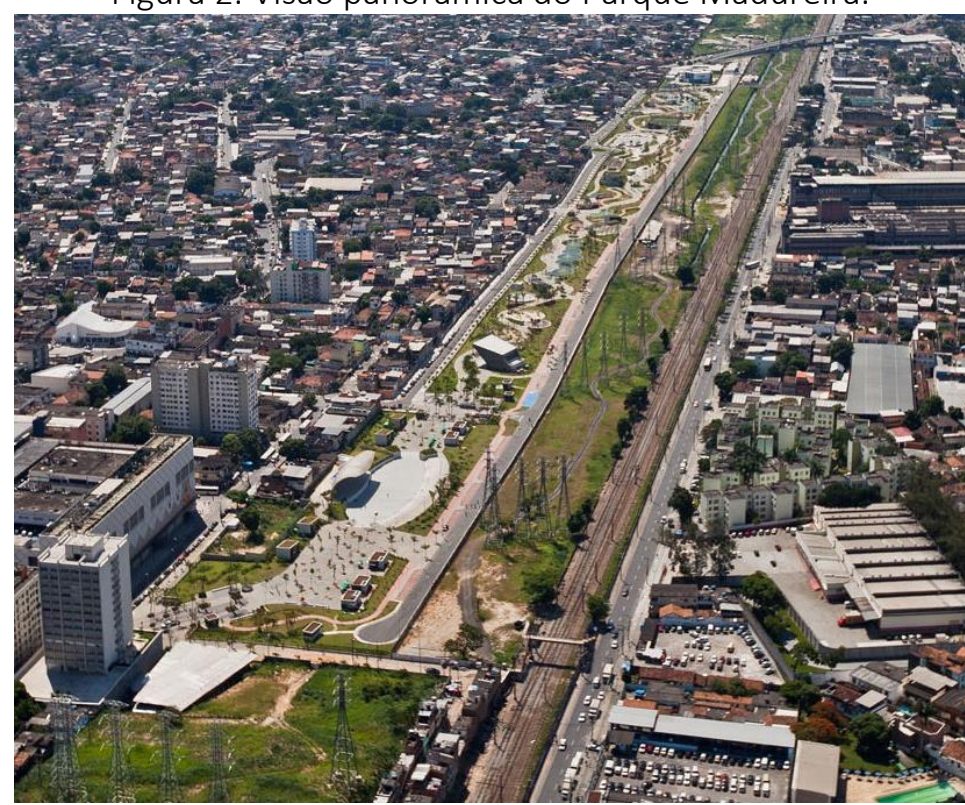

Fonte: http://pt.wikipedia.org/wiki/Ficheiro:Madureira.svg 
O Parque Madureira está situado nos fundos do Madureira Shopping e próximo do corredor da TransCarioca. É o terceiro maior parque urbano da cidade, ficando atrás apenas do Aterro do Flamengo e da Quinta da Boa Vista. O Parque apresenta uma área de 93.553,79m², numa intervenção que atinge os $108.870,32 \mathrm{~m}^{2}$, resultante da compactação de linhas de transmissão da Light que passou de $100 \mathrm{~m}$ para $40 \mathrm{~m}$. Tendo como investimento total 194.000.000,00 reais (cento de noventa e quatro milhões de reais). O projeto está dividido em cinco grandes setores que englobam e oferecem, segundo o sitio oficial do Governo, diversas opções de lazer, esporte e cultura, como: Praça do Samba; Nave do Conhecimento, parte contemplativa com: lagos, jardins sensorial e botânico, mirante, Centro de Educação Ambiental/Administração; Quadras de Esporte e Skate; Arena Carioca e Inspetoria da Guarda Municipal e ETE.

Entretanto o espaço está sendo ampliado, passará de 1,3km para 4,5km, e segundo seu projeto inicial chegará às margens da Avenida Brasil, no bairro de Guadalupe. O Decreto no 38.262 de 14 de janeiro de 2014 declara de utilidade pública, para fins de desapropriação os imóveis que se encontram nos espaços em que o Parque ocupará com sua expansão, fase essa intitulada de "Parque Madureira - 2a fase". O decreto da primeira fase não foi encontrado durante a pesquisa.

Além do Parque o bairro também é famoso por conter a atual sede das escolas de samba Portela e Império Serrano. O mesmo faz divisa com os bairros de Oswaldo Cruz, Turiaçu, Vaz Lobo, Cavalcanti, Engenheiro Leal, Cascadura e Campinho. A partir do exposto acima nota-se que Madureira é um bairro interessante de se morar, pois apresenta diversas opções de transporte, comércio e lazer próximos.

A pesquisa realizada em 2003, do Instituto Pereira Passos revelou que a produção imobiliária empresarial, quer seja no segmento comercial quer seja no residencial, abandonou o bairro Madureira em função da perda da atratividade como polo de comércio e serviços, por conta da degradação ambiental, devido ao inadequado sistema viário e do reduzido estoque de terrenos de grandes dimensões passíveis de projetos imobiliários com escala e dentro do conceito de condomínios residenciais autossuficientes. Esse abandono fez com que se gerasse como resposta uma proposta de rearticulação urbanística partindo-se da compactação das Linhas de Transmissão da Light permitindo a liberação do terreno para o desenvolvimento imobiliário e criação de áreas verdes e de lazer (IPP/SMU, 2003) para resgatar a atratividade do bairro, uma vez que possui o comércio e os serviços locais como um forte atrativo para pessoas de outros bairros, tornando-se um local muito concorrido. 
Devido ao abandono realizado pelo segmento comercial ao bairro de Madureira, os agentes públicos e privados iniciaram um processo de intervenção na área antes ocupada pelas torres de alta tensão, com a remoção das famílias que residiam e/ou trabalhavam no bairro para abrir espaço às demandas do desenvolvimento imobiliário, áreas verdes e de lazer, para que Madureira se tornasse atrativo novamente. O problema das intervenções foi a maneira como as mesmas foram conduzidas quando relacionadas a vida dos moradores/agricultores. Desrespeitando totalmente a legislação vigente que rege sobre o direito à moradia e remoções. Como será mostrado no presente texto.

Contudo, a fim de exemplificar e demonstrar os sentimentos dos moradores para com o bairro de Madureira foram transcritas algumas de suas falas para que se perceba que os mesmos não possuíam interesse algum em sair do local que moram e muito menos do bairro, mas para alcançar o objetivo esperado, liberar o espaço ocupado para a entrada das empresas imobiliárias, os moradores e agricultores foram removidos sem possibilidade de acordo, e sim imposição por parte da Prefeitura.

A Maira Rebeca ${ }^{14}$ ao ser questionada sobre o que achava do lugar que morava revelou gostar muito. "Eu não quero sair daqui não. Eu já estou acostumada a viver aqui, é perto de tudo, aqui é muito bom, tem trem, ônibus. Aqui não tem problema de enchente. Prefiro Madureira é mais animado". Apontando desta forma vontade de continuar no local que mora devido à alta disponibilidade de transportes (com trens, ônibus e os alternativos), comércio e as opções de lazer como demonstrado anteriormente no texto em tela.

O Magno Roberto ${ }^{15}$ ao longo da conversa mostrou que tem um apego muito grande pelo local em que vive, afirmando que apesar de ser uma favela por ser desprovida de investimentos públicos, com casas de estrutura desorganizadas a mesma não possui comércio de drogas, sendo assim uma das melhores para se viver, e por conta disso não possui interesse nenhum em sair da comunidade ainda remanescente. Vide a fala "...de todas as comunidades que tem aqui no Rio de Janeiro não tem nenhuma melhor para morar do que essa. Você vê essa favelinha assim, mas não tem droga, não tem boca de fumo, nada, os moradores não dão apoio a isso". E quando perguntado sobre o que esperava que ocorresse com a comunidade dentro desse processo de expansão do parque, ele falou, "eu espero que eles não façam nada aqui e que esqueçam da gente, porque eu gosto daqui". Deixando clara a necessidade e interesse de continuar no espaço e

\footnotetext{
${ }^{14}$ Entrevista 17 (Moradora Remanescente)

${ }^{15}$ Entrevista 8 (Moradores Remanescente).
} 
conservar sua fonte de renda, porque possui horta no espaço. Explicitando desta forma que gostam de Madureira, seja pelo convívio de muitos anos instalados no local, seja pelas facilidades oferecidas.

\section{COMUNIDADE DE VILA DAS TORRES}

O caso estudado refletiu o que diversas comunidades estavam passando naquele período. Revelando dessa forma não ser um caso particular e isolado a um grupo específico de pessoas (Vila das Torres), mas sim a várias comunidades (Metro-mangueira, Santa Marta, Vila Autódromo, Morro da Providência, Campinho entre outras), tanto no Rio de Janeiro, quanto no Brasil.

Depois de ter demonstrado algumas características do bairro Madureira, será relatada a visão que os próprios moradores da comunidade de Vila das Torres tinham sobre a mesma. Tal relato é importante, porque com o processo de remoção sofrido pelos moradores, os mesmos não se sentiam confortáveis para falar sobre o caso, demonstrando durante as abordagens vontade de esquecer o período em que lá viveram, acredita-se que tal sentimento se deu pela forma com que foram realizados os procedimentos de realocação. Entretanto, outros sentiam necessidade de contar sua história e relembrar cada momento vivido, pois consideravam que naquele local tinham passado por muitas coisas boas, apesar das lembranças ruins. E foi devido às ruins que a presente pesquisa pôde ser realizada.

Primeiramente vale dizer que a comunidade de Vila das Torres era considerada pelos próprios moradores, da rua Soares Caldeira até a altura da fábrica da Piraquê/muro amarelo (não existia um nome de rua), ambas localizadas no bairro de Madureira (destacado em branco na figura 3). Pois foi nesse espaço que ocorreram as primeiras construções de moradia por parte dos comodatários da Light. Entretanto, com o passar do tempo em outros espaços ao longo da linha férrea foram construídas habitações, mas eles não se reconheciam como moradores da Vila das Torres. Somente durante o processo de desapropriação tanto a Prefeitura (Secretaria de Habitação) quanto a Associação dos Moradores passou a entender toda comunidade que beirava a linha férrea, aumentando assim o número de moradores, ao longo dos bairros de Madureira, Turiaçu e Rocha Miranda, como Complexo de Vila das Torres (destacado em vermelho como é demonstrado na figura 3). 
Figura 3. O que foi considerado como Complexo de Vila das Torres e o que era entendido como.

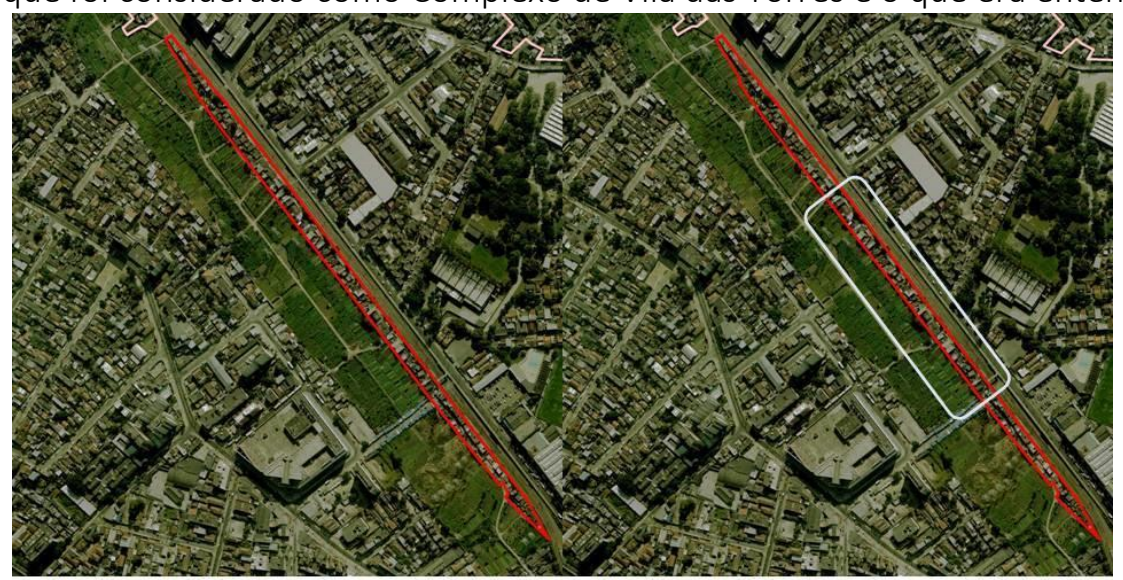

Fonte: Adaptado de Google Earth.

Para confirmar o exposto Prestes $^{16}$ alegou:

A gente só considerava a vila da Soares Caldeira até o muro amarelo, para lá para o outro lado não era a vila das torres, as casas era bem ruinzinhas, tinha mais barraco, por isso eles começaram a derrubar de lá, e quando começaram com as desapropriações, as pessoas precisavam de um documento da Associação para receber as indenizações, então tive que fazer o cadastro de todo mundo correndo, senão ninguém ia receber nada.

Mesmo o bairro Madureira apresentando diversas comunidades carentes, Vila das Torres seria a que mais contrastaria com a beleza do empreendimento que foi construído na área, devido à proximidade da mesma. Possivelmente foi esse um dos fatores que levou a necessidade de serem removidos e realocados em outros lugares para com isso se enquadrarem nas novas demandas do governo. Para confirmar a Maria $\mathrm{Ana}^{17}$ do mercadão de Madureira disse: "Eles nos tiraram dali porque não era interessante ter uma favela perto do Parque".

\section{Situação fundiária da Vila}

A partir dos gestores entrevistados não foi possível chegar a uma conclusão de quem era o terreno ocupado pelas residências, pois uns alegaram não ter dono e outro disse ser da união. Como mostram os depoimentos.

Parco $^{18}$ diz:

O terreno que foi construído o parque era da Light, onde os moradores estavam era invasão, para falar a verdade, ninguém sabe de quem era esse

\footnotetext{
${ }^{16}$ Entrevista 18 (Presidente da Associação dos moradores).

17 Entrevista 1 (Moradora/Agricultora).

${ }^{18}$ Entrevista 19 (Gestor do Parque).
} 
terreno, entre a faixa da Light e a rede ferroviária tinha uma servidão no meio e ninguém sabe de quem era, por isso que não tem informação sobre. Não tinha um dono.

Ligio ${ }^{19}$ afirma: "...onde estão as torres tinha até uma favelinha, que estava fora da área da Light, o terreno que estavam as casas não era terreno de ninguém, não tinha um dono, ninguém sabe de quem era aquilo".

Quando Ana Sofia ${ }^{20}$ foi questionada sobre quem era o dono do terreno, respondeu "eu acho que era da união. Porque as áreas que passam trem não pode ter moradia. Eu acho que não era de um particular. Tanto que a Light colocou as torres ali. Era da união".

Caso a área pertencesse à União, a possibilidade que a comunidade teria de reivindicar sua regularização na área seria através da Concessão De Uso Especial para fins de Moradia - CUEM ou Concessão de Direito Real de Uso - CDRU. Mas caso fosse de um particular seria a partir da usucapião especial urbano.

Tais mecanismos, segundo Sousa (2014, p. 2), foram conquistados devido à inclusão do "Capítulo referente à Política Urbana na Constituição (artigos 182 e 183), que, entre outros avanços, previu instrumentos aptos a legalizar assentamentos irregulares, de forma a proteger o direito à moradia das massas urbanas que possuem habitações sem segurança jurídica da posse".

A CUEM para Sousa (2014) é:

A concessão de uso para fins de moradia, um dos instrumentos utilizados para realização da regularização fundiária, diferenciando-se por se aplicar a imóveis públicos, cujo domínio não pode ser adquirido por particular, garantindo, assim, o direito à moradia às pessoas que residem nestes imóveis insuscetíveis de usucapião.

A CDRU, segundo Pinho (1998, p. 94), “...transfere direito real resolúvel sobre terrenos públicos ou particulares. ...que regulariza a situação de posse do ocupante sobre o imóvel, não acarretando a transferência da propriedade para o outorgado".

Ambos os instrumentos mencionados, CUEM e CDRU, são de direito real; contam com a possibilidade de extinção, no caso de uso diverso do imóvel pelo beneficiário e transferem o uso do bem público (ROLNIK, 2007). Entretanto possuem diferenças e para que o leitor as analise melhor foi elaborado o quadro 1.

Quadro 1. Diferenças entre CUEM e CDRU.

\begin{tabular}{|c|c|}
\hline CUEM & CDRU \\
\hline $\begin{array}{c}\text { Pode ser constituída por instrumento público ou } \\
\text { termo administrativo. }\end{array}$ & $\begin{array}{c}\text { Apenas por instrumento público ou } \\
\text { sentença judicial. }\end{array}$ \\
\hline
\end{tabular}

\footnotetext{
${ }^{19}$ Entrevista 22 (Gestor da Light).

${ }^{20}$ Entrevista 20 (Assistente Social).
} 


\begin{tabular}{|c|c|}
\hline Pode ser expedida de forma gratuita. & $\begin{array}{c}\text { Pode ser expedida de forma gratuita ou } \\
\text { remunerada. }\end{array}$ \\
\hline $\begin{array}{c}\text { Não necessita de autorização legal e de processo } \\
\text { licitatório. }\end{array}$ & $\begin{array}{c}\text { Necessita de autorização legal e de } \\
\text { processo licitatório. }\end{array}$ \\
\hline $\begin{array}{c}\text { Incide sobre o bem público (terreno e/ou imóvel } \\
\text { edificado). }\end{array}$ & \begin{tabular}{c} 
Destina-se a passar o uso do terreno. \\
\hline A expedição se faz por tempo indeterminado.
\end{tabular} \\
$\begin{array}{c}\text { A expedição se faz por tempo certo ou } \\
\text { indeterminado. }\end{array}$ \\
\hline
\end{tabular}

Fonte: Elaborado a partir da leitura de Rolnik (2007).

Para o processo de regularização fundiária em áreas de propriedade particular, tem-se a usucapião especial urbana. O artigo 183 da Constituição Federal versa: "aquele que possuir como sua área urbana de até duzentos e cinquenta metros quadrados, por cinco anos, ininterruptamente e sem oposição, utilizando-a para moradia ou de sua família, adquirir-Ihe-á o domínio, desde que não seja proprietário de outro imóvel urbano ou rural".

Durante as conversas com o Presidente da Associação Ihe foi questionado sobre a possível regularização da área e se os moradores haviam tentado em época anterior. Ele informou que a comunidade não possuía documento de posse dos imóveis. Pois quando tiveram a oportunidade de dar entrada no processo para tal, a Associação considerou melhor não fazer porque tinham familias na comunidade que não teriam condições financeiras para pagar o Imposto Predial e Territorial Urbano - IPTU, além disso, não queriam chamar a atenção para a questão da ilegalidade na ocupação da terra e por medo de serem despejados. Com isso, sairam da comunidade em 2011 considerados como invasores.

Maricato (2000a, p. 153) resume bem esse rótulo recebido pelos moradores ao dizer que "invasão é a ocupação de terras alheias, frequentemente públicas ou de propriedade confusa, por falta de alternativas, na maioria absoluta dos casos". Porque a situação fundiária da comunidade era de fato uma incógnita e sua ocupação se deu por inúmeras razões, dentre elas a falta de opção dos agricultores, a comodidade em relação a proximidade com o trabalho exercido na horta, a falta de condições financeiras dos moradores a se inserirem na cidade formal entre outras, como será visto mais adiante.

O presidente da associação durante uma das conversas disponibilizou um documento para análise escrito em Maio de 1971, pelo então presidente da Associação o Sr. Agenor Alves Barros, que retratava a situação em que a comunidade de Vila das Torres se encontrava.

Segundo o documento analisado, por volta de 1895, existia uma organização imobiliária denominada Inhaúma Irajá que loteou em Madureira uma grande faixa de terra, adquirida em 
maiores proporções na época pelo Sr. Joaquim José Marques. Ou seja, o espaço ocupado pela comunidade tinha um dono apesar de nenhum órgão o reconhecer como tal.

Essa situação possivelmente foi estabelecida por conta da promulgação da Lei de terras, que segundo Martins (2009) permitiu que posseiros comprassem lotes de terras, facilitando a divisão das grandes fazendas, o que favoreceu a ocupação de diversas regiões no Brasil, principalmente a região suburbana no Município do Rio de Janeiro.

De acordo com o documento, existia naquela ocasião, uma planta aprovada pelas autoridades locais, autorizando a abertura de diversas ruas, entre as quais para uma delas, se reservou o nome de Dr. Cincinato Lopes, que ocorrendo junto à linha de trem, ligaria as ruas Soares Caldeira e Bernardinho de Andrade.

De frente para esta rua que se chamaria Dr. Cincinato Lopes (nunca reconhecida pelas autoridades locais), havia inúmeros lotes, que posteriormente vieram a ser adquiridos pela Light, devido ao seu projeto de implantação de torres sustentadoras dos cabos de alta tensão. Os meios que a Light obteve o espaço não são explicados no documento.

Esse documento mostrou que os problemas enfrentados pelos moradores da comunidade não é um fato recente, e nem é responsabilidade apenas deles, houve uma responsabilização social e política pelo surgimento de tais assentamentos precários no bairro de Madureira, como em todo subúrbio do Rio de Janeiro.

\section{AUTOCONSTRUÇÃO NA/DA COMUNIDADE}

Após a Light adquirir o terreno para pôr as linhas de transmissão elétrica, ela permitiu que os agricultores explorassem a horticultura, para evitar invasões indesejadas, já que espaço é não edificante. Toda essa enorme faixa de terra por onde passavam os cabos de alta tensão, permitia ainda a sobra de uma pequena faixa de terra que margeiava a área cultivada. Esta sobra situa-se na área destinada aquela que seria a rua Dr. Cincinato Lopes, não reconhecida pela Administração Pública.

Segundo o documento, disponibilizado pelo Presidente da Associação dos Moradores para análise, a comunidade surgiu a partir do aproveitamento da faixa de terra que sobrara, no qual os agricultores do local iniciaram a construção de suas habitações, na época, em condições precárias. "Aquela comunidade não existia, o que existia eram algumas famílias que começaram a fazer algumas hortas, porque aquilo era uma chácara, umas pessoas portuguesas, e ai cada um foi se 
acomodando por ali", disse a Ana Sofia. ${ }^{21}$ Anos após, com a renda dos produtos da horticultura, os mesmos foram melhorando suas moradias com recursos próprios. Confirmando que a renda dos moradores locais era oriunda dos produtos cultivados sob as torres da Light, Martins (2009) alega que Madureira era favorecido por conta dos produtos agrícolas produzidos pelos primeiros emigrantes portugueses, em terras decorrentes de sucessivos fracionamentos das fazendas do Campinho e Portela.

As famílias trabalhadoras das hortas se instalaram "ilegalmente" na faixa de terra que sobrara por questões financeiras e de comodidade em relação ao trabalho exercido na área. Minimiza-se, desta forma, os gastos e tempo com transportes e deslocamento, trabalhodomicílio.

Nessa mesma linha, Alfonsin (1997) argumenta que a lógica de ocupação e urbanização das cidades, exclui a possibilidade de famílias carentes inserirem-se na cidade por meio de uma ocupação regular do espaço urbano, por conta do alto valor de mercado dos terrenos. O que faz com o que essas pessoas sem recursos financeiros ocupem terrenos ociosos, públicos ou privados, para exercer o direito de morar. E na maioria das vezes os assentamentos surgem a partir da autoconstrução.

O Estado brasileiro tolerou diversas ocupações ilegais de terra urbana, principalmente das massas de imigrantes europeus que chegaram e não conseguiram acesso ao mercado privado e nem foram atendidos pelas políticas públicas de habitação. Para Maricato (2003) foi-se admitido o direito à ocupação, mas não o direito à cidade. Ou seja, foi permitida a ocupação do espaço ocioso, entre a linha ferroviária e as torres da Light, pelos imigrantes europeus, visto que Ihes foram oferecidos serviços essenciais (como água, luz e endereço para postagens), para fazerem suas moradias, mas quando surgiu o interesse do governo e a oportunidade, foram retirados e classificados como invasores.

Para confirmar a autoconstrução na/da comunidade, foram selecionados alguns relatos para explicitar o que os primeiros moradores sentiam ou lembravam do processo de ocupação do terreno há anos atrás. Revelando a forte atuação da Associação dos Moradores.

Uma das moradoras afirmou que quando chegou ao espaço que foi ocupado pela comunidade o mesmo era vazio, sem casas e sem nenhum tipo de condições para habitar, mas com a passar dos anos os sucessivos presidentes da associação com o apoio dos moradores foram instalando os serviços básicos, como luz, água encanada entre outros. Vide a fala.

${ }^{21}$ Entrevista 20 (Assistente Social). 
Morgana22 disse:

Não lembro a data que cheguei porque eu era muito criança, mas eu sei que não tinha nada, não tinha casa, não tinha água, não tinha luz, não tinha saneamento básico nenhum, nada, era só mato, capim, esgoto... não tinha nada. Quase não tinha barraco. Nós chegamos lá (Madureira) assim, era um brejo. Meu pai veio de Minas e conseguiu ali um quarto de fundos e nós viemos. Que eu me lembre, depois de muitos anos é que veio alguma coisa. Teve um moço que entrou para presidência da associação chamado Jurandi que começou a colocar luz, porque veio a época de campanha, aí que começou uma melhoria para o povo. Depois uma água encanada, mas o esgoto continuou e a lama também. Ai depois veio o seu Agenor, seu Sebastião, dona Maria, assim depois de umas três pessoas na presidência é que começou as melhorias mesmo. Não tinha nada ali, não tinha casa de tijolo, era casa de estuque, a gente colocava ripa e fazia lama com o barro e enchia. Foi por conta da associação dos moradores que foi tendo benfeitoria na vila. Tanto os bons (presidente da associação) quanto os ruins foram melhorando a vila.

O depoimento mostra que assim que os agricultores chegaram à comunidade ela estava completamente desprovida de qualquer investimento público, era um espaço ocioso, mas com o passar do tempo os mesmos foram melhorando suas residências e o espaço de convivência comum (a rua), realizando tais melhorias por esforço dos próprios moradores com apoio e coordenação da Associação dos Moradores.

Para corroborar com os depoimentos o documento analisado informava que as melhorias na Vila, na época, foram assessoradas pela Ação Comunitária do Brasil ${ }^{23}$. A rede elétrica instalada em 1966, a rede de esgoto em 1967, a rede de água em 1968 e a sede da Associação dos Moradores em 1968. Todas realizadas com e pelos recursos dos próprios moradores, ou seja, autoconstruída. Visto que para os mesmos seria mais econômico estabelecer suas residências próximo ao local de trabalho e distribuição dos alimentos produzidos.

Amorim (2015) diz que a própria forma como as comunidades/favelas é construída fala muito sobre as relações sociais ali presentes. E na comunidade esses relacionamentos de união e esforços para melhorar o espaço comum a todos fizeram com que se criasse um sentimento familiar forte entre os moradores. Entretanto, a política habitacional ainda não os considera como

\footnotetext{
22 Entrevista 4 (Apenas Moradora).

23 Reconhecida como uma organização de utilidade pública federal (Decreto 61.593 de 23/10/1967) e estadual (Título Declaratório no 371 de 11/08/1998), a ACB/RJ foi fundada, em 17 de agosto de 1966, por um grupo de empresários, com o objetivo de melhorar a qualidade de vida de populações em situação de vulnerabilidade social, residentes em favelas e conjuntos habitacionais populares do Rio de Janeiro. Disponível em: http://www.acaocomunitaria.org.br/acb/index.php?option=com_content\&view=article\&id=121\&ltemid=119 > Acesso em: ago. 2014.
} 
importantes e prioritários e acaba rompendo os laços sociais construídos ao longo do tempo, a partir das desapropriações e realocações em lugares dispersos, com o discurso de que o Governo tem a obrigação de oferecer à população carente condições adequadas de moradia, integrando-os à cidade.

\section{INTEGRAÇÃO À CIDADE}

Toda remoção realizada tinha o objetivo de normalizar o espaço urbano, já que a presença dos moradores da comunidade, que enquanto necessária para disponibilização de mão de obra barata era tolerada, passou a não ser mais aceita na localidade. E tal transferencia, segundo alguns gestores, era considerada uma nova etapa na vida dos moradores da comunidade e a saída deles se fazia necessário para sua incorporação à cidade.

Para Brum (2013) as remoções que ocorreram nas décadas de 1960/70 serviriam para regenerar os favelados em novos ambientes e localização na cidade que seriam mais adequados a eles. Tendo a questão da ilegalidade da posse da terra, a base de toda argumentação. Assim, a promoção social do favelado deveria passar, necessariamente, pela sua elevação à condição de proprietário.

Tal argumentação foi percebida com Ana Sofia ${ }^{24}$, quando perguntado qual o sucesso do trabalho realizado junto à comunidade, respondeu:

O sucesso foi a gente ter certeza que o que nós fizemos foi o melhor que a gente tinha para oferecer para salvar as pessoas da condição de risco extremo. Porque você tirar uma familia de uma situação complicada e leva-la para uma área formal da cidade, onde as pessoas vão resgatar sua cidadania, na questão de ter endereço, morar numa area formal, ter escritura do imóvel que recebeu, ele vai viver como cidadão comum da cidade, se morrer os pais, os filhos estão amparados legalmente, porque aquilo é herança, é formal, é legal, para seus decendentes. E esse é o maior ganho que a gente pode ter.

Deixando clara desta forma que o discurso de retirar o indivíduo favelado do local de moradia e inseri-lo à cidade, ou seja, a favela não faz parte da cidade, continua sendo utilizado, disseminado e aceito pela sociedade. Utilizam como argumento o fato de ter um endereço, como se na favela não tivessem serviços de correios, ser uma situação primordial para o bem-estar do morador. Entretanto, para o indivíduo se sentir integrado à cidade, ele precisa de muito mais serviços básicos e essenciais (Escola, Hospital, Água, Luz entre outros) que um papel alegando ser proprietário de tal imóvel. Não que tais serviços não sejam oferecidos nas favelas, pois já foi

${ }^{24}$ Entrevista 20 (Assistente Social) 
mostrado que o governo por diversas vezes reconheceu a presença da mesma disponibilizando tais serviços.

Em alguns momentos da conversa foi possível perceber que $\operatorname{Parco}^{25}$ considerava que os agricultores e moradores da comunidade não estavam acostumados a viver a vida urbana, e para ele viver essa vida incluía o pagamento de taxas residenciais, como mostra em sua fala: "Ali (na vila) você não paga luz, não paga água, não paga IPTU, você vive há 40 anos assim, ai você vem e dá uma casa fora dali para eles pagarem tudo isso, eles não vão querer. Infelizmente o cara não tem essa cultura".

O problema em questão não é não ter cultura para pagar as taxas "legais", mas sim as formas como elas são cobradas em desacordo com o salário recebido pelos mesmos. Pois se é uma política habitacional para pessoas de baixa renda, de zero a três salários mínimos, os serviços como água, luz e gás devem ser cobrados com os mesmos inclusos nas tarifas sociais existentes para que não ocorra a inadimplência. Caso contrário, os problemas financeiros vão aumentar drasticamente para os moradores deslocados e "inseridos" na cidade legal.

Durante todo o processo de negociação com a Prefeitura alguns moradores que tinham a casa mais depreciada aceitaram sem nenhuma dificuldade o novo apartamento oferecido. Já os moradores que moravam há muitos anos na comunidade, que tinham passado a vida se dedicando a melhoria de sua moradia com diversos tipos de investimentos foi extremamente mais difícil convencê-los da "necessidade" de sair da comunidade para a implantação de uma área de lazer.

\section{O CONVENCIMENTO}

Para que os moradores aceitassem as negociações a Prefeitura usou alguns argumentos e se aproveitou da situação momentânea para convence-los. A Assistente Social disse que o maior desafio do trabalho deles na comunidade foi convencer os moradores a sair do coração de Madureira para um bairro distante, Realengo e Campo Grande, que não ofereciam os mesmos serviços que o bairro de origem.

Nessa direção, pode ser útil recorrer à Gramsci, como o fez Silva (2012) ao analisar a questão do convencimento, mostrando em seu texto que o mesmo representa um dos instrumentos para que a classe ou grupo dominante da sociedade capitalista exerça seu domínio,

\footnotetext{
${ }^{25}$ Entrevista 19 (Gestor Parque).
} 
sendo este não apenas capaz de impor esse domínio, mas também fazer os demais grupos sociais aceitarem-no como legítimo.

Para convencer os moradores/agricultores a Assistente Social falou sobre o risco de morte, já que tinha ocorrido chuva forte dias antes do início dos trabalhos de cadastramento, chuva esta que fez transbordar o rio e inundar algumas casas. Além das chuvas, usou-se como argumento o comprometimento do padrão construtivo das casas e a proximidade com a linha do trem. Os moradores que residiam em casas que não ficavam próximas a linha férrea foi mais difícil o convencimento, segundo Ana Sofia ${ }^{26}$. Conforme sua fala:

Calhou da semana que nós entramos na comunidade, ter chovido muito e o rio transbordou e entrou nas casas, aí a situação foi ficando complicada, aí o barranco foi desmoronando, aí existia o risco de cair no rio ou na linha do trem. Esse foi o caminho que nós encontramos para convencer as pessoas a aceitarem... E os que estavam numa situação de menos risco, tinham umas casas boas, ai, ali foi mais complicado convencer as pessoas a sairem, ai, eles receberam indenizações.

Além de usar o argumento do risco de morte dos moradores Ana Sofia ${ }^{27}$ também se organizou para levar os moradores para conhecer os apartamentos para onde seriam realocados alegando que os mesmos eram grandes, bons, o condomínio era bonito e bem tratado, os custos seriam reduzidos e que seriam proprietários dos imóveis. Mas mesmo com esses argumentos reconheceu que a falta dos serviços públicos como escola, hospital, comércios em geral dificultou o convencimento das pessoas. Como mostra em sua fala: "nós levamos os moradores para conhecer os apartamentos, nós fizemos esse trabalho de mostrar que lá era tudo bem tratado. Mas o grande desafio foi esse, escola, posto de saúde, comércio e serviços, que não tinham, aí foi difícil para convencê-los".

Outra forma de convencer os moradores a sair da comunidade sem gerarem muitos conflitos foram as propagandas midiáticas. Entretanto, essa forma já foi usada em outras situações de remoções como conta Brum (2013 p. 185)

Os governos Federal e Estadual investiam maciçamente na propaganda da casa própria e das vantagens em serviços e urbanização que os conjuntos apresentavam. Um dos pontos mais incisivos para defesa do programa de remoção por parte das autoridades: de que os favelados teriam (e queriam) a casa própria.

\footnotetext{
${ }^{26}$ Entrevista 20 (Assistente Social).

27 Entrevista 20 (Assistente Social).
} 
Tal estratégia, vantagens e desejo de se ter uma casa própria por parte da população pobre, ainda é utilizada nos meios de divulgação do Programa do Governo e na atual fase de remoções constantes pelo Brasil.

Não foram apenas essas estratégias utilizadas para convencer os indivíduos, a Prefeitura

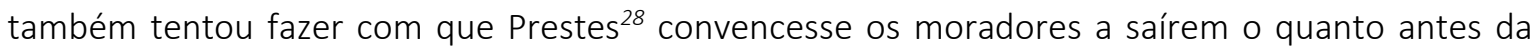
comunidade, mediante uma gratificação como: "ofereceram dois apartamentos, a sindicância lá de Realengo e mais a indenização da minha casa". Isso foi confirmado quando o gestor do Parque alegou que para convencer os moradores primeiramente é necessario descobrir quem é a liderança da comunidade e "conversar" com ela.

O medo, a falta de tempo hábil para se organizar e o desconhecimento da legislação a seu favor, podem ter sido os motivos que contribuíram para que as pessoas (a grande maioria) não entrassem em conflito com a Prefeitura após o anuncio da implantação do Parque na localidade. Foi notável também que tinham outros motivos para o não conflito, em relação às hortas, vide a fala de Mario Augusto ${ }^{29}$ :

A tentativa de nos organizarmos não deu certo, porque algumas se beneficiam e outras não, pois alguns que entraram nessa briga viram depois que isso não ia dar certo porque a Light deixou bem claro que se alguém entrasse na justiça contra ela não seria favorecido mais para frente em nada (se referia aos terrenos), então eu não briguei com ela, vi que não seria legal porque eu precisava do terreno dela para trabalhar, e depois com o tempo ela me cedeu outro terreno em Colégio, o que tenho hoje para plantar, toda plantação de horta aqui no Rio de Janeiro se resume a terrenos da Light, toda faixa da Light tem plantação. Hoje no Rio de Janeiro não tem plantação senão nos terrenos cedidos pela Light, por isso precisava dela.

Isso revela que os agricultores não entraram em conflito para reivindicar a sua permanência, ou melhor, indenização devido às benfeitorias (plantação, casa, poços entre outros) realizadas no terreno, pois não tinham outro lugar para plantar no município do Rio de Janeiro a não ser os terrenos da empresa. E caso tivessem algum desentendimento com a mesma perderiam a possibilidade de dar continuidade à prática que já é pressionada pela expansão urbana.

Outra forma de convencer as pessoas foi proporcionar uma situação difícil para os moradores, viver nos escombros. E essa foi a situação que mais mexeu com eles, porque as famílias que aceitavam as negociações tinham suas casas imediatamente derrubadas, logo a luz e água eram cortados, e esses cortes e derrubadas sempre implicava nas casas vizinhas que ficavam com suas estruturas, já frágeis, abaladas. Além disso, ocorriam infestações de pragas urbanas (ratos,

\footnotetext{
${ }^{28}$ Entrevista 18 (Presidente da Associação).

${ }^{29}$ Entrevista 3 (Morador/Agricultor).
} 
baratas, moscas entre outros) e invasão por dependentes químicos para saques as casas. Isso fez com que a aceitação do acordo dos que tinham a intenção de resistir para receber melhores indenizações, já que não tinham mais apartamentos disponíveis, se tornasse inevitável.

Um dos exemplos de imposição de poder por parte do Poder Público para com os moradores foram as ameaças realizadas para que os mesmos aceitassem a quantia - pequena oferecida pela indenização da casa ou a ida ao apartamento. Como será mostrado.

\section{AS AMEAÇAS}

Durante as conversas foi constatado em diversos depoimentos que os moradores foram ameaçados pelos técnicos responsáveis pelo processo de retirada dos moradores.

Marisa ${ }^{30}$ disse: "Eles disseram que já tinham esperado demais e que iam colocar a casa abaixo com nós dentro se não saíssemos. Teve um cara da Prefeitura, o beltrano, disse que eu ia morar embaixo da ponte. Eles não têm ética não, tem estudo, mas são tudo mal educado. Tinha um moço dizia que a gente estava tendo o que merecia. Ele colocava muito terror nas pessoas".

Prestes $^{31}$ alegou:

Eles obrigavam as pessoas a aceitarem a indenização e às vezes as pessoas queriam ir para o apartamento. Eles ofereciam um valor baixíssimo pela casa, e dizia que se a pessoa não aceitasse que ia parar um caminhão na porta dela e levar as coisas dela para um deposito público, ela ainda teria que pagar a diária, que ia depositar o dinheiro dela em juízo, e que ia derrubar a casa dela, aí a pessoa se desesperava e aceitava. De dez conversas na secretaria de habitação, as dez não concordam, mas três negociam por medo, porque viam que já estava acontecendo diversos Monalisa ${ }^{32}$ informou: assaltos, invasões e tudo mais, e o restante não.

Quando a gente entrava na Prefeitura para conversar com eles sobre a avaliação da casa, parecia uma lavagem cerebral. Entravamos vestidos e saíamos pelados. Eles falavam um monte, 'ah que vocês têm que sair logo, e de qualquer jeito, porque senão o trator vai chegar lá vai derrubar e vai ser assim mesmo. Querendo ou não é melhor aceitar'. Teve uma vez que eu só saí da Prefeitura dez e pouca da noite com minha filha, porque disse que só sairia de lá quando minha filha ganhasse os direitos dela porque ela tem Déficit de Atenção.

Tais depoimentos foram expostos em sequência para que o leitor possa perceber o quão ruim foi para os moradores passar pelo processo de remoção da comunidade, sem possibilidade de

\footnotetext{
${ }^{30}$ Entrevista 13 (Moradora).

${ }^{31}$ Entrevista 18 (Presidente da Associação).

${ }^{32}$ Entrevista 6 (Moradora).
} 
acordo ou conversa, restando somente as imposições da Prefeitura para que aceitassem a qualquer custo o oferecido e saíssem do local para dar prosseguimento às obras que precisavam ser inauguradas no ano de 2012, eleições municipais, porque o mesmo tinha tomado à implantação do Parque como política de governo.

E como mostrado anteriormente, a comunidade de Vila das Torres não se enquadrava as novas demandas da gestão governamental - entregar o bairro ao capital imobiliário - que agia sobre o processo de deslocamento dos moradores para construção do Parque, sendo necessária sua realocação em bairros mais periféricos, aumentando a segregação espacial da pobreza.

\section{LEGISLAÇÃO URBANA E SEGREGAÇÃO ESPACIAL DA POBREZA}

Desde anos remotos a favela é considerada como elemento ilegal e marginal na paisagem urbana, sendo logicamente incapaz de integrá-la ao restante da cidade, visto que este fato impedia o investimento público nestes espaços. Entretanto, foram promulgadas leis e decretos que asseguravam as primeiras iniciativas de urbanização (SOARES, 2014).

Segundo o documento elaborado pelo Ministério das Cidades $^{33}$ o Brasil passou por um processo acelerado de urbanização nos últimos 50 anos e hoje, cerca de $85 \%$ da população brasileira vive em áreas urbanas, onde se concentram, também, a pobreza e a precariedade. Sendo desta forma inevitável a criação de políticas públicas urbanas para o enfrentamento dessas desigualdades.

E em meio a esse contexto o Brasil passou por processos de reformas constitucionais e legais para conseguir criar programas sociais, urbanos e habitacionais. O primeiro passo, segundo descrito no documento, foi o reconhecimento da função social da propriedade e da cidade a partir de uma nova ordem urbanística mais justa, includente e democrática. Iniciado com a incorporação da questão urbana na Constituição Federal de 1988 que ensejou a inclusão, nas constituições estaduais e nas leis orgânicas municipais. Com isso, o texto constitucional afirma o papel protagonista dos municípios enquanto principais atores da política de desenvolvimento e gestão urbana e elege o Plano Diretor como instrumento básico da política de desenvolvimento e de expansão urbana.

No ano de 2000, o direito à moradia digna foi reconhecido por uma emenda constitucional, tornando-se uma referência para as políticas urbanas e habitacionais. Em 2001, a Lei no 10.257,

${ }^{33}$ Disponível em: < http://www.un.org/en/ecosoc/integration/pdf/brazil.pdf > Acesso em: jan. 2015. 
conhecida como o Estatuto da Cidade, regulamentou os artigos constitucionais sobre desenvolvimento urbano e introduziu uma nova ótica de planejamento construída sob uma perspectiva de gestão participativa e controle social. Este definiu o Plano Diretor do município. Em 2003, foram criados o Ministério das Cidades e o Conselho Nacional das Cidades com o compromisso de desenvolver e implementar a Política Nacional de Desenvolvimento Urbano. Em 2005, o Ministério das Cidades com o apoio do Conselho das Cidades lançou a Campanha Nacional "Plano Diretor Participativo - Cidade de Todos".

A partir daí foram estruturadas políticas e programas voltados à habitação, ao saneamento básico, ao transporte público coletivo e à mobilidade urbana, à regularização fundiária, à prevenção de riscos, dentre outros, de modo a reverter o passivo de desigualdade social das cidades brasileiras. Criadas as condições jurídicas e institucionais foi criado o programa nacional de investimentos em infraestrutura urbana e de habitação de interesse social: o Programa de Aceleração do Crescimento - PAC.

O PAC representou um avanço, pois ampliou o acesso a bens e serviços urbanos, representando a retomada dos investimentos na política urbana, contudo pontos negativos também foram encontrados, principalmente referentes à participação popular, do Conselho e Ministério das Cidades, quanto à transparência de suas ações, visto que retirou a centralidade das decisões dos órgãos citados.

Para, Santos (2011), a lógica da implementação das obras tem sido mais importante do que a lógica do planejamento e da participação popular, como previsto inicialmente pelo Ministério das Cidades, dessa forma, interrompe ou bloqueia a ampla participação no desenho das políticas e programas de desenvolvimento urbano e investimentos futuros. Segundo ele, os projetos aprovados pelo PAC não foram objeto de debate e deliberação no Conselho Nacional das Cidades.

Completando, Rolnik (2015) diz que quando altas quantidades financeiras são disponibilizadas para investimentos na urbanização das favelas do país - como o PAC das favelas o que se observa é a desconstituição dos processos e fóruns participativos e diversos processos massivos de remoção em decorrência da implementação de projetos e obras, muitas vezes com uso da violência.

A urbanização de favelas pode até melhorar as condições de moradia e segurança, os problemas de saneamento ambiental e atribuir endereço legal aos moradores, entretanto, não melhora os níveis de escolaridade, não organiza um padrão de vida melhor (MARICATO, 2013) que 
são pontos importantes para se minimizar os problemas sociais da cidade, como a pobreza para assim reduzir a zero a segregação espacial tão visível nos grandes centros urbanos.

Mesmo com todos esses instrumentos urbanísticos citados Rolnik (2015) afirma que por mais que existam tais que garantam a plena segurança da posse, o sistema oficial de financiamento do desenvolvimento urbano jamais os reconheceu, tendo como base apenas as escrituradas em cartório. E Maricato (2000a), completa dizendo que não é por falta de planos e nem legislação específica que as cidades brasileiras crescem de modo predatório. O que acontece é a forma discriminatória da aplicação desses instrumentos urbanos, favorecendo pequenos interesses corporativos. Em outro texto, Maricato (2013) escreve que as conquistas formais nunca serão suficientes, pois tudo depende dos interesses em jogo. Ou seja, aprovar a lei no Congresso Nacional é um desafio, aplica-la, em nível municipal, é outro, porque depende do enfrentamento dos proprietários fundiários e imobiliários que estão longe de ser um setor frágil na sociedade brasileira.

Maricato $(2015$, p.4) afirma também que os "padrões modernistas detalhados de construção e ocupação do solo, presentes nas leis de zoneamento, código de obras, leis de parcelamento do solo, convivem com a gigantesca cidade ilegal onde a contravenção é regra".

Para Compans (2007) o tema do direito à cidade surgiu a partir do processo constituinte através do Movimento Nacional pela Reforma Urbana, sendo consagrado tanto na Constituição Federal de 1988, quanto nas constituições estaduais, nas leis orgânicas e Planos Diretores municipais. O direito à cidade se traduziu no reconhecimento dos espaços ocupados irregularmente pela população pobre e na extensão a estes de todos os benefícios advindos da urbanização.

Inicialmente serão demonstrados alguns dos princípios que constam no Plano Diretor da Cidade $^{34}$, aprovado em 1992. Em seu artigo 44 que dispõe sobre o uso e ocupação do solo urbano versa que respeitaram a não remoção de favelas e sua inserção no planejamento da Cidade com vista à sua transformação em bairros ou integração com os bairros em que se situam.

Entretanto estão sujeitas a relocalização as áreas de favelas e assentamentos irregulares que ocupem:

1. Áreas de risco;

2. Faixas marginais de proteção de águas superficiais;

3. Faixa de proteção de adutoras e de redes elétricas de alta tensão; 
4. Faixa de domínio de estradas federais, estaduais e municipais;

5. Áreas de especial interesse ambiental ou unidades de conservação ambiental;

6. Vãos e pilares de viadutos, pontes e passarelas e áreas a estes adjacentes, quando oferecerem riscos à segurança individual e coletiva e inviabilizarem a implantação de serviços urbanos básicos; e

7. Áreas que possam ser dotadas de condições mínimas de urbanização e saneamento básico. Compans (2007) alega que consideradas as características de relevo e hidrografia da cidade do Rio de Janeiro, somadas ao processo histórico de ocupação pelos pobres das áreas impróprias à urbanização (encostas ou nas margens de rios, canais, córregos e lagoas) tal dispositivo resulta na anulação do princípio da não remoção para grande parte das favelas cariocas, visto que a maior parte das ocupações irregulares ocorre nas áreas citadas como sujeitas a relocalização.

No mesmo documento, o artigo 138, que versa sobre a política habitacional do Município visa assegurar o direito social de moradia e reduzir o déficit habitacional, pela realização de relocalização prioritária das populações assentadas em áreas de risco, com sua recuperação e utilização imediata e adequada, entretanto a ordem de preferência dos deslocamentos devem seguir: I - reassentamento em terrenos na própria área; II - reassentamento em locais próximos; III - reassentamento em locais dotados de infraestrutura sanitária e transporte coletivo; IV - inserção em outros programas que contemplem a solução da questão habitacional. Todavia tais preferências não foram respeitadas quando deslocaram a comunidade de Vila das Torres para o PMCMV-Realengo, porque não Ihes deram nenhuma das opções, apenas impuseram aos moradores a aceitação do acordo com valores irrisório de indenização ou a ida para o apartamento do PMCMV-Realengo.

Para Maricato (2013) é preciso mudar a concepção do Plano Diretor, porque há décadas o mesmo tem cumprido mais um papel ideológico do que instrumento de orientação da gestão e dos investimentos nas cidades brasileiras.

No momento far-se-á o uso da Lei Orgânica do Município do Rio de Janeiro (LOMRJ), visto que a mesma é bem avançada e tem diversas salvaguardas, ou seja, instrumentos no município que amparam os removidos.

A LOMRJ em seu Artigo 429 que trata da Política de desenvolvimento urbano versa que deverão ser respeitados os preceitos da urbanização, regularização fundiária e titulação das áreas faveladas e de baixa renda, sem remoção dos moradores, salvo quando as condições físicas da área ocupada imponham risco de vida aos seus habitantes, no entanto caso a localidade ofereça riscos o 
procedimento deve ser seguido do laudo técnico do órgão responsável; da participação da comunidade interessada e das entidades representativas na análise e definição das soluções; e do assentamento em localidades próximas dos locais da moradia ou do trabalho, se necessário o remanejamento (Grifos nossos).

Ou seja, o processo de remoção das famílias para localidades próximas só se dará quando detectado a existência de risco de morte insanável, que não possa ser solucionado por intermédio de obras de urbanização ou estabilizantes, assegurada a participação da comunidade ou de seus representantes em todo o processo.

Quanto ao laudo técnico, Compans (2007), afirma que a avaliação dos riscos geológicos, bem como a análise da possibilidade de realização de obras estabilizantes compete a um único órgão, integrante da administração local: a GEO-Rio. E a detenção de um conhecimento altamente especializado dificulta a contestação de seus pareceres pelas comunidades afetadas, convertendose em algo irrefutável e inquestionável.

Mesmo o Brasil apresentando diversos instrumentos legais que garantem os direitos da população carente quanto à moradia, como mostrados, eles estão sendo violados com ações rígidas e impositivas por parte da Prefeitura, sem mecanismos de participação e de mediação e resolução de conflitos.

Completando o exposto, Rolnik (2015) revela que por mais que exista legislação implementada no país quanto urbanização de favelas, a luta cotidiana dos assentamentos informais e ocupações no país para resistirem às remoções e expulsões violentas e se integrarem definitivamente a cidade é bem mais complexa e contraditória. O problema das remoções não é a falta de instrumento e sim o não cumprimento dos existentes. Visto que as estruturas administrativas urbanas estão viciadas de procedimentos baseado no privilegio e na troca de favores (MARICATO, 2013) sendo essa uma situação corriqueira na esfera pública quando dominada por interesses privados, que mantém com padrões satisfatórios apenas uma parte das cidades. O que faz gerar a segregação social e isolar a maior parte da população, a pobre, em áreas que os serviços públicos e básicos não chegam.

O inciso IV, do Art. 30 da LOMRJ, descreve que deve haver a urbanização das áreas faveladas e loteamentos irregulares, integrando-os aos bairros onde estão situados. Ou seja, integra-los e não isola-los. Abramo (2003) diz que ter acesso a serviços urbanos é uma variável importante na qualificação da moradia popular. 
É possível pensar a partir do exposto, na "periferização" da população pobre, como Silva (2012) afirma a partir do reassentamento habitacional do Programa Minha Casa Minha Vida, o que faz diminuir as possibilidades das famílias removidas em obter emprego e ascender socialmente. Concordando com a importância da localização residencial dos moradores pobres, Abramo (2003) diz ser um fator que potencializa ou reduz os níveis de bem-estar familiar, pois podem causar acesso ou exclusão as redes de serviços e equipamentos urbanos.

Concordando com Silva, Amorim (2015) afirma que no caso especifico do PMCMV no município do Rio de Janeiro percebe-se essa periferização sim da população de baixa renda, da faixa de 0 a 3 salários mínimos, pois seus empreendimentos são construídos em locais distantes e sem infraestrutura, por serem mais econômicos para as construtoras que tem o interesse em maximizar seus lucros.

De acordo com Cardoso (2011), a constatação da periferização da moradia social é perceptível ao se visualizar os mapas de distribuição dos empreendimentos construídos, ficando claro que a maioria dos projetos elaborados para a faixa de 0 a 3 salários mínimos está localizada a AP 5 (Área de Planejamento 5), que cobre boa parte da zona oeste da cidade. A zona oeste é a área da cidade menos urbanizada, possui diversos problemas de integração com a cidade e problemas de infraestrutura básica como falta de saneamento básico. A comunidade estudada na pesquisa foi realocada para a AP 3, na zona norte da cidade. Essa zona é intensamente ocupada e vem sofrendo, através de um processo de especulação imobiliária, uma valorização de seus imóveis.

Para Santos (1988) tal isolamento só favorece a morte do bom relacionamento entre as pessoas. Separar os pobres em bairros distantes é impedi-los de ficarem juntos as melhores oportunidades de trabalho.

Maricato (2013) alega "a produção da moradia exige um pedaço de cidade e não de terra nua". Ou seja, não basta disponibilizar a moradia em lugares sem estrutura para absorver a população. Para a autora, nas políticas de habitação de interesse social deve-se realizar um "mix" de apartamentos para diversas faixas de renda em um mesmo empreendimento, para talvez minimizar essa exclusão.

Para Peixoto (2013) o projeto de urbanização não pode ser imposto à comunidade, ele deve ser levado à discussão, com construção de soluções que respeitem as necessidades e 
escolhas da população do local. No entanto, as comunidades como um todo, geralmente, são agentes passivos ${ }^{35}$ das remoções que estão ocorrendo.

Silva (2012) escreve em seu trabalho que as mesmas pessoas (moradores da comunidade de Vila das Torres) que construíram sua história há décadas no bairro de Madureira não poderão, em sua maioria, desfrutar dos benefícios da construção de um parque público na região, pois alguns foram realocados para bairros muito distantes $(19 \mathrm{~km})$ ou sofreram muito com o processo de remoção e não querem voltar ao local por medo da lembrança. E que a desocupação do terreno com a retirada dos agricultores/moradores de Madureira, articulava-se com um contexto específico da cidade do Rio de Janeiro, ilustrando tendências da gestão urbana contemporânea marcadas pela compreensão de certas localizações como estratégias para o capital; pela Parceria Pública Privada estabelecida pela Prefeitura-Light-Delta; e pelo desrespeito e indiferença com relação à população carente.

Quando Costa e Rego (2013) escreveram um artigo falando sobre as hortas de Madureira, alegaram que o governo do Estado do Rio de Janeiro, "ignorando as territorialidades, identidades territoriais e as relações identitárias há décadas ali constituídas e fixadas sobre aquele espaço social pretendia impor seu poder coator, sua ordem superior e findar uma trilha histórica ali materializada espacialmente".

Em relação às favelas, Barreira e Botelho (2013) alegam que se "afastadas dos terrenos mais valorizados da cidade ou, pelo menos, localizadas de forma a não saltar a vista, não são apenas toleradas como até são necessárias". Corroborando com isso, Fridman (1992) alega em seu trabalho que no contexto de crise habitacional, ao qual passou o Rio de Janeiro em determinados momentos, as favelas não eram o problema, mas sim a solução para a garantia do direito à moradia para a população mais pobre. Essas afirmações ajudam refletir sobre os possíveis motivos da existência da comunidade de Vila das Torres na região durante tanto tempo.

Segundo Santos Junior (2011) nossas cidades possuem um modelo de propriedade da terra urbana que impede certos grupos de apropriar-se coletivamente da cidade, ou seja, de ter acesso à moradia e a usufruir do bem-estar proporcionado pelos equipamentos coletivos da cidade. Por mais que os bairros carentes (suburbanos) necessitem de equipamentos de lazer para seus moradores é importante saber quem será o público a utilizar tal empreendimento e quais serão as consequências da implantação do mesmo. Pois como já dito anteriormente, as reformas urbanas

\footnotetext{
${ }^{35}$ Passivos porque sofre ou recebe uma ação sem reagir contra ela.
} 
são necessárias, entretanto a forma com que as mesmas são realizadas (desrespeitando a legislação vigente) é desnecessária.

\section{MINIMIZAÇÃO DOS DANOS DOS DESLOCAMENTOS INVOLUNTÁRIOS}

Para tentar minimizar os danos causados à população deslocada o Ministério das Cidades emitiu uma portaria (317/2013), mais um instrumento garantindo direitos às famílias passiveis de serem removidas, que dispõe sobre medidas e procedimentos a serem adotados nos casos de deslocamentos involuntários de famílias de seu local de moradia ou de exercício de suas atividades econômicas, provocados pela execução de programas e ações, sob gestão do Ministério das Cidades, inseridos no Programa de Aceleração do Crescimento - PAC.

No documento está descrito que o deslocamento de famílias que estejam residindo ou desenvolvendo atividades econômicas nas áreas de intervenção somente deve ser realizado quando imprescindível para:

1. Execução ou complementação de execução de obras voltadas à implantação de infraestrutura;

2. Implantação de intervenções que garantam soluções habitacionais adequadas e urbanização de assentamentos precários.

É permitido o deslocamento com a condição de reposição da moradia para as famílias afetas nos casos necessários para:

1. Eliminação de fatores de risco ou de insalubridade a que estejam submetidas às famílias, tais como inundação, desabamento, deslizamento, tremor de terra, proximidade à rede de energia de alta tensão, ou em solo contaminado, somente quando a eliminação desses fatores não se constituir em alternativa econômica ou socialmente viável;

2. Recuperação de áreas de preservação ambiental ou faixa de amortização, em que não seja possível a consolidação sustentável das ocupações existentes; ou

3. Desocupação de áreas com gravames ou restrições absolutas para fins de ocupação humana, conforme definido em legislação específica.

Mostrando desta forma mais um avanço na proteção do direito à moradia digna, visto que este é o primeiro ordenamento jurídico brasileiro a regulamentar esse tipo de situação, no entanto o mesmo necessita ser executado pelos responsáveis por tal procedimento para que a população deslocada obtenha o mínimo de perdas possível. 


\section{CONSIDERAÇÕES FINAIS}

Ao estudar a comunidade de Vila das Torres foi possível perceber, primeiramente, que ela possuía um histórico de formação a partir da agricultura estabelecida nas faixas de transmissão da empresa Light numa área que não era reconhecida pelas autoridades governamentais. Segundo que ela apresenta questões que são percebidas tanto na literatura quanto na fala dos entrevistados. A saber: A situação fundiária da comunidade era conflitiva; desenvolveu-se a partir da autoconstrução e até os dias atuais se consideravam moradores da vila ao identificarem as benfeitorias realizadas pelos próprios (como poste de luz, medidor de luz, árvores plantadas, muros e etc.) e carregam o ressentimento de terem saído.

A comunidade ainda apresenta moradores remanescentes que não possuem o interesse em sair de sua comunidade; A Agricultura Urbana tinha uma importância para quem praticava, mas tal importância desapareceu devido ao evento, instalação do Parque Madureira; Os trabalhadores da horta possuíam um contrato de comodato com a empresa Light e a disponibilização do terreno para horticultura se deu há muitos anos atrás aos portugueses, devido a uma política de imigração implantada pelo Governo da época.

Em relação à instalação do empreendimento objeto de nossa atenção - o Parque Madureira - procurou-se mostrar que ele se coaduna com a gestão da cidade baseada em reformas e renovações urbanas, atualmente com Megaprojetos, implicando, sempre que necessário, o deslocamento involuntário das famílias carentes, que estão instaladas nos locais por onde ocorram as obras. Os deslocamentos são crônicos na sociedade brasileira, ou seja, o presente trabalho não mostrou um fato novo ocorrido no município do Rio de Janeiro, mas sim, mais um dos diversos que já ocorreram e continuam acontecendo.

Sendo este apenas a demonstração da forma atualizada e contemporânea de realizar as remoções que sempre houveram da população de baixa renda. Retirar a população desrespeitando a legislação que rege sobre o caso sempre foi o modelo de gestão dos "Governos Remocionistas". A diferença é que atualmente as ações estão mais desrespeitosas, mais opressivas, mais agressivas. Com isso, pode-se concluir que a aceitação da permanência de moradores irregulares em determinado local da cidade tem o propósito de realizar um estoque de terras, a qual será usada no momento em que o Governo achar conveniente e para isso basta retira-los. Independente do instrumento urbanístico que poderia ter sido utilizado para regularizar a situação fundiária dos moradores. 
Tanto o projeto urbanístico implantado em Madureira como o mapeamento de áreas de risco na Comunidade - proximidade com a linha férrea, com um córrego e com as torres de alta tensão - eram tecnicamente questionáveis, poderiam ser modificados para se adequarem de modo que não houvesse quaisquer remoções/deslocamento dos moradores do bairro, já que os primeiros projetos já tinham sido elaborados com este fim. Com isso, conclui-se que as famílias foram removidas em vão, que na verdade o que estava em jogo era a possibilidade de dar forças à especulação imobiliária que os agentes públicos e privados buscavam no bairro, ao racismo e ao elitismo da classe média que queria ver longe seus vizinhos favelados, negros e pobres.

Diante do exposto, foi possível concluir também que o objetivo da remoção dos moradores/agricultores para a implantação do Parque Madureira era a disponibilização da área, em questão, para usos "mais nobres" e não a manutenção da Agricultura Urbana atrelada a uma comunidade carente, como era. Mesmo que isso viesse causar danos irreparáveis a pequena população de mais de 800 (oitocentas) famílias da Vila.

Caso os gestores envolvidos no processo tivessem planejado alguma estratégia que incorporassem os agricultores a nova lógica local, como estava no projeto inicial, esses e outros problemas sociais não seriam tão visíveis, visto que a Agricultura Urbana complementa as práticas agrícolas realizadas em meio rural, para com isso enfrentar, segundo Mougeot (2015) os desafios do desenvolvimento, dentre eles a pobreza urbana. Essa complementaridade se dá em termos de autoconsumo, fluxos de comercialização e fluxos de abastecimento do mercado.

Com isso, fica clara a importância de se pontuar a maneira surpreendente e desrespeitosa que a Prefeitura e o Governo do Estado conduziram o processo de remoção/deslocamento dos moradores. Como visto, eles ameaçaram, mentiram, enganaram, passaram informações desencontradas, permitiram que a empresa Light pressionasse os agricultores, enfim usaram diversos artifícios para oprimir a população residente no local. Dando um exemplo de como o Poder Público não deve agir, visto que é papel do Estado proteger o cidadão.

Desta forma, a intenção deste trabalho foi mostrar a realidade desses processos de remoção, os conflitos e resistências por eles gerados, com vistas a contribuir para um novo olhar sobre tais processos que inspire procedimentos mais respeitosos e iniciativas de apoio aos moradores removidos. 


\section{REFERÊNCIAS BIBLIOGRÁFICAS}

ABRAMO, P. A cidade da informalidade $O$ desafio das cidades Latino-americanas. Rio de Janeiro, Livraria Sette Letras, FAPERJ, 2003.

ALFONSIN, Betânia de Moraes. Direito à moradia: instrumentos e experiências de regularização fundiária nas cidades brasileiras. Rio de Janeiro: IPPUR / FASE, 1997.

AMORIM, T. P. Conjuntos habitacionais ou condomínios fechados? Um estudo de caso sobre os empreendimentos Ipê Amarelo e Ipê Branco em Realengo, Rio de Janeiro. Disponível em: < http://conferencias.cies.iscte.pt/index.php/icyurb/sicyurb/paper/view/270/21 > Acesso em: jan. 2015.

ARMAZEM. Bairros cariocas. Disponível em: http://portalgeo.rio.rj.gov.br/armazenzinho/web/BairrosCariocas/index2_bairro.htm > Acesso em: 09 out. 2013.

BARREIRA, M. R. A.; BOTELHO, M. L. Crise urbana e favelização no Rio de Janeiro: para uma crítica da "questão urbana" contemporânea. Disponível em: < http://www.uel.br/grupopesquisa/gepal/terceirosimposio/marcosrodrigues.pdf > Acesso em: 02 out. 2013.

BRUM, M. Favelas e remocionismo ontem e hoje: da Ditadura de 1964 aos Grandes Eventos. In: Revista PUC - O social em questão. Ano XVI, n²2, 2013.

CARDOSO, A.; ARAGÃO, T.; ARAÚJO, F. Habitação de Interesse Social: Política ou Mercado? Reflexos sobre a Construção do Espaço Metropolitano. Anais do XIV Encontro Nacional da ANPUR. Rio de Janeiro, $2011 . \quad$ Disponível em:

http://www.observatoriodasmetropoles.net/download/adauto_cardoso.pdf. > Acesso em: fev. 2015.

COSTA, V. L.; REGO, L. F. G. As hortas urbanas de Madureira a Honório Gurgel: uma primeira Aproximação. Disponível em:<http://www.pucrio.br/pibic/relatorio_resumo2008/relatorios/ccs/geo/geo_vitor_lima_costa.pdf > Acesso em: 11. Nov. 2013.

FRIDMAN, F. Propriedade fundiária, parcelamento da terra e processo de urbanização no Município do Rio de Janeiro. In: Anais do XVI Encontro Anual da ANPOCS, Caxambu-MG, 1992.

GAGLIANO, P. S. Novo curso de direito civil. Tomo II: Contratos em espécie. São Paulo: Saraiva, Volume 4, 7ạ Edição, 2014.

GODOY, A. S. Pesquisa Qualitativa Tipos Fundamentais. Revista de Administração de Empresas. São Paulo, v.35, n. 3, p. 20-29. 1995a.

Introdução à Pesquisa Qualitativa e suas possibilidades. Revista de Administração de Empresas. São Paulo, v.35, n. 2, p. 57-63. 1995b. 
INSTITUTO PEREIRA PASSOS/SECRETARIA MUNICIPAL DE URBANISMO. Prestação de serviço para formulação e execução de pesquisa qualitativa e quantitativa a ser realizada junto aos beneficiários diretos e indiretos do projeto de revitalização da área central de Madureira. Diretoria de projetos especiais. Rio de Janeiro. Dezembro, 2003.

MARICATO, E. As ideias fora do lugar e o lugar fora das ideias Planejamento urbano no Brasil. In: A cidade do pensamento único: Desmanchando consensos. Petrópolis, RJ: Vozes, 2000a.

Urbanismo na periferia do mundo globalizado. In: São Paulo em perspectiva. V. 4, no 4, São

Paulo, 2000b. 160

Metrópole, legislação e desigualdade. In: Estudos avançados. V.17, no 48, São Paulo, 2003.

Brasil, cidades: Alternativas para uma crise urbana. 6ed. Petrópolis, RJ: Vozes, 2013.

Metrópoles desgovernadas. Disponível em: <

http://www.scielo.br/scielo.php?script=sci_arttext\&pid=S0103-40142011000100002 > Acesso em: Dezembro 2015.

MARTINS, R. L. Mercadão de Madureira: Caminhos de Comércio. Carlos Joaquim. Condomínio do Entreposto Mercado do Rio de Janeiro, 2009.

OLIVEIRA, C. L. Um apanhado teórico-conceitual sobre a pesquisa qualitativa: tipos, técnicas e características. Revista Travessias. Disponível em:<file:///C:/Users/Juliana\%20Arruda/Downloads/3122-11555-1-PB\%20(5).pdf > Acesso em: Abril de 2014.

PEIXOTO, H. M. A remoção e a Lei Orgânica do Município do Rio de Janeiro. Disponível em:<http://direitoeurbanismo.wordpress.com/2013/03/19/a-remocao-e-a-lei-organica-domunicipio-do-rio-de-janeiro/ > Acesso em: Nov. 2013.

PINHO, E. B. Regularização fundiária em favelas. In: FERNANDES, EDÉSIO (org). Direito urbanístico. Belo Horizonte: Del Rey, 1998.

ROLNIK, R. (org). Regularização fundiária plena: referências conceituais. Brasília: Ministério das Cidades, 2007. 304p.

10 Anos do Estatuto da Cidade: Das Lutas pela Reforma Urbana às Cidades da Copa do Mundo. Disponível em: < https://raquelrolnik.files.wordpress.com/2013/07/10-anos-do-estatuto-dacidade.pdf >Acesso em: Jan. 2015.

SANTOS, C. N. F. A Cidade como um jogo de cartas. Universidade federal Fluminense: EDUFF, 1988.

SANTOS, M. R. M. Apontamentos para uma agenda de democratização da política municipal de desenvolvimento urbano. In: Políticas públicas e direito à cidade: programa interdisciplinar de formação de agentes sociais e conselheiros municipais. Rio de Janeiro: Letra Capital: Observatório das Metrópoles: IPPUR/UFRJ, 2011.

SANTOS JUNIOR, O. A. A Produção Capitalista do Espaço, os Conflitos Urbanos e o Direito à Cidade. In: Políticas públicas e direito à cidade: programa interdisciplinar de formação de agentes sociais e conselheiros municipais. Rio de Janeiro: Letra Capital: Observatório das Metrópoles: IPPUR/UFRJ, 2011. 
SILVA, L. C. Projeto urbanístico e impactos habitacionais: o caso da implantação do parque de Madureira, Rio de Janeiro. Monografia - Curso de Especialização em Política e Planejamento Urbano do Instituto de Pesquisa e Planejamento Urbano e Regional - Universidade Federal do Rio de Janeiro - UFRJ, 2012.

SOARES, R. G. A política, o direito e as favelas do Rio de Janeiro: um breve olhar histórico. Disponível em: < http://www.soma.org.br/arquivos/FavelasDoRioPoliticaDireitoOlharHistorico.pdf > Acesso em: Nov. 2014.

SOUSA, L. S. C. A constitucionalidade do aspecto temporal na regulamentação da concessão de uso especial para fins de moradia (CUEM). Disponível em: < http://jus.com.br/artigos/25213/aconstitucionalidade-do-aspecto-temporal-na-regulamentacao-da-concessao-de-uso-especial-parafins-de-moradia-cuem\#ixzz3K6AKyJ14 > Acesso em: Nov. 2014.

VIEIRA, N. P.; BAGNATORI, M. I. Apontamentos sobre urbanização de favelas, remoções de moradias e trabalho social na cidade de São Paulo. In: Revista PUC - O social em questão. Ano XVI, $n^{\circ} 29,2013$.

Trabalho enviado em 03 de outubro de 2015.

Aceito em 24 de janeiro de 2016. 